Pamiętnik Literacki 2021, 2, s. 55-64

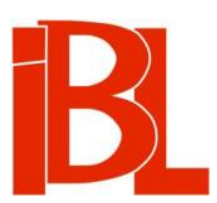

\title{
Orientalne lektury Krasickiego - przyczynek do badań nad erudycją pisarza
}

Klara Leszczyńska-Skowron 
Pamiętnik Literacki CXII, 2021, z. 2, PL ISSN 0031-0514

DOI: $10.18318 / \mathrm{pl} .2021 .2 .4$

KLARA LESZCZYŃSKA-SKOWRON Instytut Badań Literackich PAN, Warszawa

\section{ORIENTALNE LEKTURY KRASICKIEGO - PRZYCZYNEK DO BADAŃ NAD ERUDYCJĄ PISARZA}

Wśród wielu cech, jakie można przypisać Ignacemu Krasickiemu, jedną z najpełniej zaznaczających się w jego życiu i twórczości była niewątpliwie erudycja ${ }^{1}$. Dowód na wagę, jaką XBW przywiązywał do lektury, stanowi choćby jego biblioteka, której różnorodność pozwala objąć i docenić praca Jadwigi Rudnickiej i Sante Graciottiego $^{2}$. Książki i czytelnictwo powracały też jako temat chyba we wszystkich dziełach ${ }^{3}$ niewłaściwe lektury psuły młodego Doświadczyńskiego i żonę modną, bohaterkę satyry, do czytania tych właściwych zachęcał Krasicki w „Monitorze”, w Panu Podstolim i Uwagach doradzał, jak wyposażyć bibliotekę. Ostatni $z$ wymienionych utworów pełen jest zresztą śladów lektur Księcia Biskupa, zarówno tych nieświadomych, przypadkowych reminiscencji, jak i wyrażonych wprost opinii, odwołań i ocen, przytoczonych cytatów. Nawiasem mówiąc, trudno się dziwić, Uwagi są wszak zbiorem esejów, a ten gatunek dialogiczność - i to nie tylko na poziomie nadawca-odbiorca, lecz także na wyższym, Bachtinowskim, między myślą a myślą, tekstem a tekstem ${ }^{4}$ - ma wpisaną w samą swoją istotę ${ }^{5}$. Wśród wielu ksiag, książek i książeczek wymienionych, wspomnianych, zacytowanych w zbiorze, wśród niemal intymnych zwierzeń urzeczonego czytelnika i słów krytyki nasyconych ironią, znajdują swoje miejsce dwa ciekawe dzieła, jak się wydaje - szerzej znane na zachodzie

1 Ewidentnie widać to np. w artykule M. Górskiej (O wyborze ksiag i bibliomanii: „Biblioteki”. W zb.: Czytanie Krasickiego. Red. T. Kostkiewiczowa, R. Doktór, B. Mazurkowa. Warszawa 2014), w którym autorka tropi mniej i bardziej wyraźne ślady lektur I. Krasickiego.

2 Inwentarz biblioteki Ignacego Krasickiego z 1810 r. Oprac. S. G ra ci o t ti, J. Ru d nicka. Wrocław 1973.

3 Zob. T. Kostkiewiczowa, „Ksieggi, wiersze, dzienniki...” O pogladach na ksiażki i czytanie w epoce oświecenia i pismach Ignacego Krasickiego. W: Studia o Krasickim. Warszawa 1997.

4 M. Bachtin (Problemy poetyki Dostojewskiego. Przeł. N. Modzelewska. Warszawa 1970, s. 134) pisał o F. Dostojewskim, że „odkrył [on] dialogową naturę wszelkiej idei, wszelkiej świadomości oraz wszelkiej działalności, choćby tylko częściowo świadomej”.

5 Z. Gierczyński (wstęp w: M. de Montaigne, Próby. Ks. 1. Przeł. T. Żeleński〈Boy〉. Oprac., wstęp, koment. Z. Gi i r c zy ń s ki. Wyd. 2. Warszawa 1985, s. 40) pisze: „Próby [...] roją się od cytatów łacińskich (greckie są nieliczne), spotyka się je niemal na każdej stronie. Nie służą one zresztą tylko ozdobie dzieła: często Montaigne posługuje się nimi dla wyrażenia myśli, których nie chce wyrazić po francusku”. S. Bla c k (Of Essays and Reading in Early Modern Britain. Basingstoke 2006, s. 20) natomiast tak definiuje esej: „W eseju tworzy się przestrzeń, w której refleksja nad myśla jest ważniejsza niż jej pochodzenie, przestrzeń, w której powtórzenie myśli jest wybaczalne przez sam fakt, że została znów użyta czy też - co nieuniknione - użyta w nowy sposób". Jeśli nie zaznaczono inaczej, wszystkie przekłady - K. L.-S. 
Europy niż w Rzeczypospolitej. Celem niniejszego artykułu o rysie przyczynkarskim jest właśnie wskazanie na te „europejskie” lektury Krasickiego.

\section{Przestrogi, które Nabi Effendi synowi swojemu zostawił}

W Uwagach wśród zamieszczonych utworów, balansujących na pograniczu klasycznego eseju i charakterystycznego dla XVIII-wiecznych periodyków angielskich periodical essay, wypracowanego przede wszystkim przez Josepha Addisona i Richarda Steela w tygodniku „The Spectator”, znajduja się też zbiory maksym wyjęte $\mathrm{z}$ różnych źródeł (czasem wymienionych w tytule, np. Zdania filozofów z Diogenesa Laercjusza czy Maksymy Teognisa z Megary, a czasem nie, np. Myśli, Myśli różne). Zbiory te składają się wyłącznie $z$ sentencji mniej lub bardziej uporządkowanych tematycznie, niepołączonych $\mathrm{w}$ żaden sposób ${ }^{7}$. Jednym $\mathrm{z}$ nich są właśnie Przestrogi, które Nabi Effendi synowi swojemu zostawit. W najnowszym wydaniu Uwag w opracowaniu Zdzisława Libery znaleźć można tylko wyjaśnienie (zaczerpnięte zresztą ze Zbioru potrzebniejszych wiadomości ${ }^{8}$, co pozwala czytelnikowi poznać ówczesny stan wiedzy i objąc szerszym spojrzeniem horyzonty wiedzy Księcia Biskupa) tytułu effendi, nie ma jednak informacji, kim ów Nabi był ani jak trafił do dzieła Krasickiego. Obecnie dostęp do księgozbiorów i łatwość wyszukiwania informacji, jaką oferuje badaczom różnych dziedzin nowoczesna technologia, ułatwiają poszukiwanie odpowiedzi na tego rodzaju pytania.

W roku 1770 we Francji ukazało się 2-tomowe dziełko zatytułowane Mêlanges de littérature orientale (Miscellanea literatury orientalnej) ${ }^{9}$, które wyszło pod nazwiskiem Denisa-Dominique’a Cardonne’a, tłumacza z jezzyków orientalnych, opiekuna królewskiej biblioteki i profesora Collège Royal, jak przeczytać można na stronie tytułowej. O samym autorze dużo więcej nie wiadomo. Urodził się w 1721 roku, zmarł w 1783 roku, 20 lat życia spędził w Konstantynopolu, był autorem Histoire de l'Afrique et de l'Espagne sous la domination des Arabes (Historii Afryki i Hiszpanii pod panowaniem arabskim), oraz przełożył m.in. również bajki Bidpaia (w dziełach Krasickiego zapisywanego jako Pilpaj ${ }^{10}$ ) i Amstala Lokmana el-Hakima. We wstępie można jeszcze znaleźć informację, że zdecydował się wydać Mélanges de littérature orientale ze względu na zainteresowanie czytelników taką literaturą, o czym świadczył sukces Tysiaca i jednego dni oraz Tysiaca i jednej nocy ${ }^{11}$. Przy-

6 Definicję tej odmiany eseju podaje J. M. Ku ist (Periodical Essay. Hasło w: Encyclopedia of the Essay. Ed. T. Chevalier. London 2006, s. 1375-1377).

7 Kierując się zacytowaną wcześniej definicją Blacka, można również uznać, że w zbiorze esejów znajduje się miejsce dla tych sentencji. Wspomina o nich i poddaje tropy genologiczne D. Kali n o w s k i („Uwagi” Ignacego Krasickiego na tle europejskiej tradycji pism moralistycznych. „Słupskie Prace Filologiczne. Seria Filologia Polska” 2002, s. 28).

8 Zob. Z. Libera, przypisy w: I. Krasicki, Uwagi. Wstęp, oprac. Z. Libera. Warszawa 1997, s. 411.

9 Mélanges de littérature orientale. Traduits de différens manuscrits turcs, arabes et persans de la Bibliothèque du Roi par D.-D. C ard on n e. T. 1-2. Paris 1770.

10 Zob. bajkę I. Krasi ckiego Gołębie (w: Pisma poetyckie. Oprac. Z. Goliń ski. T. 2. Warszawa 1976, s. 157) z drugiej części Bajek nowych z dopiskiem „Z indyjskiego Pilpaja” i artykuły Lokman i Pilpaj (w: Dzieła. Nowe i zupełne wydanie. T. 3. Wrocław 1824).

11 Chodzi o dzieła Les Mille et Un Jours, contes persans P. De La C r o ix i Les Mille et Une Nuits A. Gallanda. 
wołuje w nim zresztą nazwiska swoich poprzedników na polu literackim - Pétisa de la Croix, Antoine’a Gallanda i Barthélemy'ego d'Herbelot. Cardonne pragnie, jak pisze, uzupełnić ich dzieła drobiazgami wybranymi z królewskiej biblioteki. Wśród tych drobiazgów - anegdot, opowieści, poezji - znajduje się też „traktat o wychowaniu, czyli rady ojca dla jego syna, pióra Nabiego Effendi" ${ }^{12}$. Traktat ten opatrzony jest tytułem Conseils de Nabi Efendi à son fils (Rady Nabiego Effendi dla jego syna), przetłumaczonym dosłownie przez Krasickiego. Kompilacja Cardonne’a cieszyła się chyba sporą popularnością, gdyż wydano ją w wersji 2-tomowej również w 1772 roku i w roku 1788 w jednym tomie, w którym - jeśli wierzyć informacji na stronie tytułowej - znalazły się także fragmenty tłumaczone przez Gallanda ${ }^{13}$. W roku 1771 ukazał się po raz pierwszy angielski przekład zatytułowany A Miscellany of Eastern Learnings (Zbiór nauk wschodnich) ${ }^{14}$, drugą edycję wydano rok później ${ }^{15}$. O ich poczytności świadczyć może występowanie odwołań i cytatów w tak zróżnicowanych pozycjach, jak „The Lady’s Magazine”, gdzie znajdują się dwa „rozdziały" Conseils (poświęcone bogactwu i szyderstwu) jeszcze w języku francuskim (zaczerpnięte wprost z Mélanges) ${ }^{16}$; The Modern, Polite, and Fashionable Letter Writer (Współczesny grzeczny i modny korespondent) ${ }^{17}$, gdzie fragment rozważań o poezji przedstawiony jest w formie listu, odwołanie do tej części Conseils pojawia się także na marginesie poematu Living Poets and Poetesses (Żyjący poeci i poetki) Nicholasa Michella ${ }^{18}$, na stosunek Nabiego do alchemii powołuje się The Encyclopaedia Britannica ${ }^{19}$, a profesor Warington W. Smyth cytuje go w swoim wykładzie o mineralogii i sztuce wydobywczej ${ }^{20}$. O tym, że traktat służy jako ilustracja kultury tureckiej w The Present State of Turkey (Obecny stan Turcji) Thomasa ThornBibliothèque du Roi par D.-D. Cardonne. On y a joint les paroles remarquables et les bons mots des Orientaux, suivant la traduction de A. Galland. Traduit dans le siècle dernier par A. Galland. La Haye 1788.

14 Odnotowuje go np. katalog W. M a r s d e n a (A Catalogue of Books and Manuscripts Collected with a View to the General Comparison of Languages, and the Study of Oriental Literature. London 1827, s. 262): „1771. A Miscellany of Eastern Learning. Translated from Turkish, Arabian, and Persian Manuscripts, by M. Cardonne. Translated into English. London 1771, 12mo", w części Catalogue of Works Chronologically Arranged in Each Class of Language, w dziale Polyglot. Universal. Oriental. General.

Wspominają o tym fakcie redaktorzy „The Monthly Review” (t. 46 〈January/June〉〈1772〉, s. 624), choć nie mają o tym wydaniu najlepszej opinii: „Ponieważ teksty w tym zbiorze dobrane są przypadkowo i bez troski o wybór, nie przynosi on chwały swojemu twórcy, a jeszcze mniej przynosi jej przekład w tej [drugiej] edycji angielskiemu tłumaczowi. Pierwszemu zabrakło smaku i zdolności sądzenia, drugi, oprócz braku tychże, zdaje się nie rozumieć nie tylko języka francuskiego, lecz także ojczystego". „The Lady's Magazine” 1771 (November), s. 224.

The Modern, Polite, and Fashionable Letter Writer: Consisting of Select and Original Letters, in Elegant and Choice Language, on All Important Subjects of Life [...]. Introd., study E. S e a f o r th. London [1855], s. 135.

N. M i c h e 11, Living Poets and Poetesses. A Biographical and Critical Poem. London 1832, s. 27. Alchemy. Hasło w: The Encyclopaedia Britannica. A Dictionary of Arts, Sciences, and General Literature. Ed. W. H. De puy. T. 1. Chicago 1895, s. 464.

W. W. S m y th, On the Value of an Extended Knowledge of Mineralogy nad the Processes of Mining. (Being the Introductory Lecture to the Course of Mineralogy and Mining). „Records of the School of 
tona ${ }^{21}$, można by nawet nie wspominać. W publikacji o takiej tematyce odniesienia do Conseils są raczej oczywiste.

Krasicki w swojej bibliotece miał egzemplarz Mélanges (nie był to zapewne przypadek, jeśli wziąc pod uwagę, że $z$ wymienionych przez Cardonne’a autorów w jego księgozbiorze znaleźć można zarówno Baśnie tysiaca i jednej nocy (Les Mille et Une Nuits) w przekładzie Gallanda, jak i Bibliothèque orientale (Bibliotekę orientalna) d'Herbelota ${ }^{22}$, i to $\mathrm{z}$ tego wydania Mélanges najprawdopodobniej zaczerpnał materiał do rozdziału w Uwagach. Cardonne zamieścił Conseils w swoim dziele, opatrując je przypisem, w którym oprócz krótkiego objaśnienia, kim był Nabi, powtarzał wyrażoną już we wstępie myśl:

Przekonałem się, że tłumaczenie tych rad mogłoby być interesujące, ponieważ może nam dać wyobrażenie o moralności Turków. Bylibyśmy najpewniej zaskoczeni, widząc, że myślą oni o wielu rzeczach podobnie do nas; a zatem idee uczciwości, sprawiedliwości i cnoty są takie same u wszystkich ludów ${ }^{23}$.

Niewykluczone, iż przekonanie to podzielał i XBW, dlatego zdecydował się przybliżyć swoim czytelnikom rady Nabiego w przekładzie Cardonne’a. Nietrudno było dać wiarę słowom Francuza, czytając jego elegancki, czysty i zwięzły przekład. Krasicki wybrał z niego to, co było mu bliskie, czasem tłumacząc dosłownie, często - jak miał w zwyczaju, choćby adaptując artykuły z tygodnika „The Spectator” skracając i wydobywając samo sedno refleksji. Jako egzemplifikacja może posłużyć rozdział Sur le vin et sur l'opium (O winie i opium), który polski pisarz ujął w jedną myśl: „Pijaństwo jest rzeczą sprosną, zelżywą; nie tylko pijaka trzeźwy, ale i zwierzę zawstydza" ${ }^{24}$. W wersji francuskiej po pochwale wina użytego w mierze znaleźć można fragment, który najbliższy jest sensem aforyzmowi Krasickiego:

Wino degraduje tego, kto je pije w nadmiarze, i sprawia ono, że tracimy rozum, który powinien być naszym przewodnikiem; rujnuje ono naszą reputację i zamyka nam na zawsze drogę do zaszczytów i godności ${ }^{25}$.

Warto zwrócić uwage, że przytoczone w tym cytacie argumenty niemal dokładnie pokrywają się z tymi, $\mathrm{z}$ których korzystał młody ksiądz Krasicki w artykułach zamieszczonych w „Monitorze” przeciw pijaństwu ${ }^{26}$. Czasami zachował metafory, dodając do nich krótkie objaśnienie, jak w przypadku aforyzmu o nauce: „I w na-

Mines and of Science Applied to the Arts" t. 1, cz. 1 (1852): Inaugural and Introductory Lectures to the Courses for the Session 1851-1852, s. 125.

21 Th. Th or nt on, The Present State of Turkey: or Description of the Political, Civil, and Religious, Constitution, Government, and Laws of the Ottoman Empire. T. 1. Wyd. 2, popr. i uzup. London 1809, s. 62-63.

Zob. Pozycja [1421]: Nouveau mélange de littérature orientale par mr Cardonne. Paris, vol. 2, broché. W zb.: Inwentarz biblioteki Ignacego Krasickiego z 1810 r., s. 123. - Pozycja [1447]: Mélange de littérature orientale par mr Cardonne. Tomów $2 \mathrm{w}$ lej księdze, en broché, in $8 v o$. W zb.: jw., s. 125. Pozycja [1152]: Les Mille et Une nuits. Genève, 9 tomes, 1790, avec figures, en veau, in 8vo. W zb.: jw., s. 100. - Pozycja [538]: Bibliothèque orientale ou dictionnaire universel par mr d'Herbelot. 4to $\langle$ ?〉 vol., carton, in 4 to. W zb.: jw., s. 57. Mélanges de littérature orientale. Traduits de différents manuscrits turcs, arabes et persans de la Bibliothèque du Roi. Par D.-D. C a rd on n e. [Wyd. 2.] T. 2. Paris 1772, s. 162-163, przypis (a). I. Kr a s i c ki, Przestrogi, które Nabi Effendi synowi swojemu zostawił. W: Uwagi, s. 385.

Mélanges de littérature orientale, t. 2 (1772), s. 198.

„Monitor” 1766, nry 14, 19, 31, 81. 
ukach, i w każdej porze życia bez pracy i cierpliwości nic się stać nie może; bez bicia w skrzydła ptak nie podleci; kruszec głęboko i perly w morzu są na dnie"27, w tłumaczeniu Cardonne'a zaczynającym się od zachęty do czytania najlepszych autorów, po której następuje już fragment przełożony przez XBW:

Czy ptak bez skrzydeł ośmiela się wzbić w powietrze? Drogocenna muszla, która otacza perłę, nie znajduje się na powierzchni wody; to z głębi morza i pokonując tysiące niebezpieczeństw, trzeba ją wylawiać $^{28}$.

Podane egzempla stanowia jedynie rzut oka na przyzwyczajenia translatorskie Księcia Biskupa, którym należałoby poświęcić uwagę badawczą.

Warto jeszcze zadać pytanie, kim był Nabi Effendi, który pozostawił po sobie te przestrogi. Według współczesnych źródeł Nabi Yusuf urodził się w Urfie w roku 1642, zmarł w 1712 roku w Stambule, był mistrzem gazelu, stosował styl kwiecisty, tworzył poezję w językach arabskim, tureckim i perskim, a wśród jego najsławniejszych dzieł znajdują się Nasihatname-i Ebulhayr (〈Księga rad dla Ebulhayra〉, zwana też Hayriye), Münşeat (listy) oraz Fethname-i Kameniçe (Księga o zdobyciu Kamieńca) ${ }^{29}$. $\mathrm{Z}$ przypisów i wstępów dowiedzieć się można, że był też zaufanym sułtana lub paszy $^{30}$ Mustafy $^{31}$, po śmierci którego złożył urząd i osiadł w Aleppo, gdzie stworzył wierszowany zbiór porad dla swojego, wówczas 8-letniego, syna ${ }^{32}$. Kilka lat później został wezwany do Konstantynopola ${ }^{33}$, gdzie mieszkał do końca życia. Wszyscy autorzy, którzy poruszali kwestie biograficzne czy to w przypisie, czy we wstępie, podkreślają, że Nabi był wśród swoich rodaków uważany za znakomitego poetę oraz prozaika i jego dzieła należą do klasyki literatury tureckiej.

Zainteresowanie utworem Nabiego najsłynniejszym również w jego ojczyźnie było dość długotrwałe. W roku 1857 pojawił się nowy francuski przekład wydany wraz z tureckim oryginałem oraz obszernym komentarzem. Autorem tego przekładu był Abel Pavet de Courteille, orientalista i - podobnie jak jego poprzednik - profesor Collège de France. Tłumaczenie de Courteille’a znacząco różni się od wersji Cardonne’a. Przede wszystkim nie jest to zbiór sentencji i porad, lecz spójny tekst, choć także napisany prozą. Zawiera też cechy charakterystyczne dla kultury, w której powstał, zwłaszcza kwiecisty i bogaty język, pełen apostrof, metafor i porównań. W zestawieniu z jasną i prosta, wolno chyba zaryzykować twierdzenie - oświeceniową prozą Cardonne’a, wydaje się rzeczywiście egzotyczny. Za przykład posłużyć może choćby początek rozdziału poświęconego nauce. Oto tłumaczenie de Courteille’a:

Kr a s i c ki, Przestrogi, które Nabi Effendi synowi swojemu zostawit, s. 382.

Mélanges de littérature orientale, t. 2 (1772), s. 180.

Zob. Nabi Yusuf. Hasło w: Encyklopedia PWN. Na stronie: https://encyklopedia.pwn.pl/haslo/ Nabi-Yusuf;3945030.html (data dostępu: 13 II 2021).

Zob. Mélanges de littérature orientale, t. 2 (1772), s. 162. Zob. też S m y th, op. cit., s. 125. - Conseils de Nabi Efendi à son fils Aboul Khair. Publiés en turc avec la traduction française et des notes par A. Pavet de Courteille. Paris 1857, s. I.

W rzeczywistości był to wielki wezyr Kara Mustafa, z którym Nabi Yusuf wyprawił się na wojnę z Polską. Brał wtedy udział w oblężeniu i zdobyciu Kamieńca Podolskiego, co zresztą opisał. Zob. Biographical Encyclopaedia of Islam. Ed. M. T. H o u t s m a. New Delhi 2006, s. 901. - Islâm Ansiklopedisi. Na stronie: https://islamansiklopedisi.org.tr/nabi/ (data dostępu: 14 II 2021).

Conseils de Nabi Efendi à son fils Aboul Khair, s. 4.

Ibidem, s. I. 
O, młody krzewie, ozdobo łąki edukacji, ty, który oświecasz serce i oczy twojego ojca, poświęć noc i dzień studiowaniu szlachetnej nauki; nie pozostawaj nieokrzesańcem pograżonym w ignorancji ${ }^{34}$.

„Poświęć, mój synu, świeżość swojego umysłu studiowaniu nauk ścisłych; one są nieskończoną wartością w życiu” - pisze Cardonne ${ }^{35}$.

Różnice są wyraźne. Co ciekawe, de Courteille, mimo że zatytułował swój przekład dokładnie tak samo jak jego poprzednik, we wstępie nie wspomniał nawet o wcześniejszym o ponad pół wieku dziele Cardonne’a, ani o jego angielskich tłumaczeniach. Natomiast praca Courteille'a została odnotowana na Wyspach Brytyjskich, informacja o jej ukazaniu się pojawiła się w „The Eclectic Magazine of Foreign Literature, Science and Art” w czerwcu 1857 z komentarzem: „Uznani badacze kultury orientalnej potwierdzili, że jest to dobrze wykonane tłumaczenie” 36 . Wzmianki o dziele Nabiego są też podawane czy to jako przykład orientalnej moralistyki w artykule poświęconym charakterowi Turków, czy to jako komentarz do Księgi Przysłów ${ }^{37}$. W wieku XIX ma miejsce jeszcze jeden epizod polski tureckiego pisarza. W ósmym tomie Nowego Korbuta uwieczniony jest Antoni Muchliński, orientalista. Wśród jego licznych prac z zakresu historii, językoznawstwa czy geografii, w dziale Przekłady znaleźć można następujący zapis: „Przekład Hajrije, poematu obyczajowego osmańskiego poety Nabi-effendi” ${ }^{38}$. Tajemnicze Hajrije (we francuskiej wersji Khairiyé) to nic innego jak Przestrogi, które Nabi Effendi synowi swojemu zostawit, a zatem mniej więcej w tym samym czasie, gdy pojawiło się francuskie tłumaczenie de Courteille'a wierne oryginałowi, powstało także polskie, jak można się domyślać, uwzględniając wykształcenie Muchlińskiego, wierniejsze oryginałowi niż zapośredniczona wersja Krasickiego. Niestety rękopis owego przekładu zaginął. Gdyby tak się nie stało, prawdopodobnie tajemniczy Nabi Effendi z Uwag byłby lepiej znany polskiemu odbiorcy.

\section{Myśli i zawarte w nich nauki Hikara wezyra dla syna jego, Nadana}

Przestrogi, które Nabi Effendi synowi swojemu zostawił sa ostatnim rozdziałem w Uwagach Krasickiego. Poprzedza je zbudowany w podobny sposób zbiór aforyzmów zatytułowany lakonicznie Myśli. Znajdują się w nim różne aforyzmy, anegdota o Mikołaju Mileckim i Janie Zamoyskim czy o kardynale Richelieu. Czytamy w krótkim wprowadzeniu:

Hikar, wezyr sułtan [! $]^{39}$, doszedłszy lat zgrzybiałych, otrzymał pozwolenie złożyć urząd, który przez

Ibidem, s. 13.

Mélanges de littérature orientale, t. 2 (1772), s. 177.

„The Eclectic Magazine of Foreign Literature, Science and Art” 1857 (June), s. 288.

W. R. S. Rals to n, Turkish Story-Books. „The Nineteenth Century. A Monthly Review” 1877, t. 1 (March/July), s. 24. - S. C. M a l a n, Original Notes on the „Book of Proverbs”. Mostly from Eastern Writings. T. 2. London 1892, s. 317-318.

Muchliński Antoni. Hasło w: Nowy Korbut. T. 8: Romantyzm. Hasła osobowe K-O. Oprac. Zespół pod kier. I. Śliwińskiej i S. Stupkiewicza. Warszawa 1969, s. 430.

To prawdopodobnie literówka, w edycji XIX-wiecznej jest „wezyr sułtana” - zob. I. Kra sicki, Przestrogi, które Nabi Effendi synowi swojemu zostawił. W: Dzieła. T. 6: Dzieła proza. Edycja nowa i zupełna. Red. F. K. D m o c h ow s ki. Warszawa 1803, s. 442. 
długi czas chwalebnie piastował; a że monarcha chciał mieć syna jego Nadana po nim następca, takie mu ojciec na piśmie przesłał nauki $[\ldots]^{40}$.

Potem pojawia się niezbyt długi ciąg złotych myśli dotyczących właściwego stosunku do objętej władzy, pochlebstwa, bogactwa, relacji do pana i do podwładnych. Ciekawy zbieg okoliczności, iż na końcu Uwag Księcia Biskupa znajdują się dwa zbiory rad ojców dla synów, zaczerpnięte $z$ kultury Orientu, pisane przez osoby obdarzone wysokim statusem społecznym. Dodać można jeszcze, że znów XBW przeszczepia na grunt polski fragmenty dzieła należącego do klasyki twórczości Wschodu. Różnica między tymi dwiema pracami wynosi jednak prawie tysiąc lat. Wypada zaczać od sprostowania - wezyr nie nazywał się Hikar, lecz Ahikar, wymieniony z imienia Nadan nie był jego synem, lecz siostrzeńcem, adoptowanym i wychowywanym jak syn. Sama historia zaś pochodzi z VI bądź V wieku przed Chrystusem i uznaje się ją za jedno z pierwszych dzieł literatury międzynarodowej, jako że cieszyła się sławą na całym Bliskim Wschodzie, w zachodnioeuropejskim kręgu kulturowym jej tytuł tłumaczono jako The Story of Ahikar, Words of Ahikar, Histoire et sagesse d'Ahikar l'Assyrien, a nawet - w polskim przekładzie z 2010 roku - jako Historia i madrość Achikara Asyryjczyka. Sama opowieść jest prosta: Ahikar, skryba Sennacheryba i Asarhaddona, by mieć dziedzica, adoptuje siostrzeńca Nadana, potem zaś przedstawia go swojemu panu $z$ myślą, że zostanie on jego następcą. Nadan rzeczywiście przejmuje urząd po wuju, po czym spiskuje, by oskarżyć go o zdradę stanu i pozbawić życia. Spisek się udaje, ale Ahikar unika śmierci za sprawą wdzięcznego strażnika więziennego. $Z$ czasem spisek zostaje odkryty, Ahikar oczyszczony z zarzutów, a Nadan ukarany. Taka jest główna fabuła opowieści, w innych wersjach wzbogacona o historię o wyprawie Ahikara do Egiptu, gdzie bohater odpowiada na pytania Faraona i zadziwia go swoja mądrością. Dzieje Achikara uzupełniają dwa zbiory maksym, czyli właśnie owa Sagesse d'Ahikar (Mądrość Ahikara), analogiczna do Mądrości Syracha czy Księgi Madrości ${ }^{41}$. Historia Ahikara miała wiele przekazów, od syryjskich, aramejskich czy arabskich, po greckie czy staro-cerkiewno-słowiańskie. Sam Ahikar zaczynał jako politeista, lecz z czasem w różnych wersjach przedstawiany był jako wyznawca religii monoteistycznej. Wpływów opowieści upatruje się zarówno w biblijnej Księdze Tobiasza lub w Nowym Testamencie, jak i w twórczości Demokryta, Teofrasta, Menandra, w historii Ezopa czy wspomnianego już Lokmana. Według tradycji Ahikar pojawia się w Księdze Tobiasza jako bratanek Tobiasza-ojca. W Wulgacie występował pod imieniem Achior, a Nadan jako Nabat. I rzeczywiście w przekładzie Biblii pióra Jakuba Wujka znajduje się krótkie zdanie: „I przyszli Achior i Nabat, cioteczni bracia Tobiaszowi, weseląc się, do Tobiasza, i radując się z nim ze wszystkiego dobra, które przeciw niemu Bóg był pokazał" (Tb 11, 20) ${ }^{42}$.

41 Głównym źródłem wiedzy o Ahikarze w mojej pracy jest wstęp F. Nau do wydania Histoire et sagesse d'Ahikar l'Assyrien (fils d'Anael, neveu de Tobie) (Traduction des versions syriaques avec les principales differénces des versions arabes, arménienne, grecque, néo-syriaque, slave et roumaine. Introd., trad. F. N a u. Paris 1909).

42 Biblia $w$ przekładzie księdza Jakuba Wujka z $1599 \mathrm{r}$. Transkrypcja typu „B” oryginalnego tekstu z XVI w. i wstępy ks. J. Fra n k ow ski. Wyd. 3. Warszawa 2000, s. 790. 
Wybrane przez Krasickiego maksymy pochodzą więc $z$ tekstu stanowiącego niewątpliwie fundament zarazem dla literatury Bliskiego Wschodu, jak i śródziemnomorskiej. Wagę dzieła doceniano w Europie Zachodniej, badając je i tłumacząc praktycznie od początku XVIII wieku ${ }^{43}$. Autor przekładu z 1909 roku, François Nau, wymienia zarówno francuskie, jak i niemieckie tłumaczenia nowożytne. Sam zaś, choć opiera się na wersji syryjskiej, wskazuje także różnice między odmiennymi rękopisami, tworząc rozbudowany i budzący podziw aparat krytyczny.

Czy zatem Książę Biskup miał świadomość, że dla swoich czytelników czerpał mądrość ze źródła tak dawnego i poważnego? Najprawdopodobniej nie. Wersja, którą znał Krasicki, pochodziła bowiem z kolekcji Le Cabinet des fées (Gabinet wróżek), będącej dodatkiem czy też kontynuacją Baśni tysiaca i jednej nocy ${ }^{44}$. Dzieje Ahikara nosiły w owym wydaniu tytuł Histoire de Sinkarib et ses deux vizirs (Historia Sinkariba i jego dwóch wezyrów). Pozycja ta znajdowała się w książęcej bibliotece ${ }^{45}$, Krasicki mógł więc $z$ łatwością sięgnąc po nią przy pracach nad artykułami do Uwag. Jak pisał Nau:

Ogólnie rzecz biorąc, w wydaniu Le Cabinet des fées dialogi są wydłużone i wymyślone, wyolbrzymiona została rola żony Ahikara; tymczasem przysłowia często są nowe i występują mniej licznie niż w innych edycjach ${ }^{46}$.

I rzeczywiście - w porównaniu z 95 maksymami w pierwszej i $46 \mathrm{w}$ drugiej serii mądrości Asyryjczyka - Histoire de Sinkarib zawiera ich stosunkowo niewiele, bo tylko 28, a Krasicki wybrał $\mathrm{z}$ nich 18.

Przekład jest, jak na Księcia Biskupa, bardzo wierny, prawdopodobnie dlatego, że w wydaniu z Le Cabinet des fées same maksymy ujęte zostały zwięźle, wydobywając esencję lub trafnie podsumowując kilka sentencji $z$ oryginału. Przykładowo w edycji Nau na początku rad Ahikara padają takie zdania:

Tak, mój synu Nadanie, jeśli słuchasz moich słów, zamknij je w Twoim sercu i nie ujawniaj ich innym, z obawy przed piecem ognistym, który może spalić Twój język i spowodować ból ciała i chorobę Twojego umysłu [...]. O, mój synu, jeśli słyszysz słowo, nie ujawniaj go nikomu i nie mów nic o tym, co widzisz [...]. O, mój synu, kieruj Twą ścieżką i Twoim słowem, słuchaj i nie spiesz się $z$ daniem odpowiedzi ${ }^{47}$.

Zamiast tych zdań Denis Chevis w swoim przekładzie Le Cabinet des fées notuje krótko: „Sekret, który się wymyka, pali język; hałas, który poprzedza projekt lub mu towarzyszy, niszczy go" ${ }^{8}$, co Krasicki tłumaczy wiernie, acz jeszcze zwięźlej: „Sekret objawiony pali język; ogłoszone przedsięwzięcie psuje dzieło” ${ }^{49}$. Prześledzenie sposobów „zagęszczania” treści w jak najkrótszej, najprostszej do zapamiętania formie - w czym XBW jako autor Bajek i przypowieści wykazał się prawdziwym

Najstarsze wymienione przez $\mathrm{Na}$ u (op. cit., s. 15) tłumaczenie pochodzi z 1708 roku.

Continuation des Mille et Une Nuits, contes arabes. Traduits littéralement en françois par D. C h avis. Rédigés par J. Cazotte. T. 2. Paris 1788.

Pozycja [1152], s. 100. Edytorzy wyjaśniają, że z tych dziewięciu tomów pięć pierwszych było w przekładzie Gallanda, a cztery następne w przekładzie Chavisa i Cazotte’a oraz że był to przedruk $\mathrm{z}$ wydania w Le Cabinet des fées.

$\mathrm{Na}$ u, op. cit., s. 15.

Histoire et sagesse d'Ahikar l'Assyrien, s. 154-156.

Continuation des Mille et Une Nuits, s. 277.

Krasicki, Myśli, s. 379. 
mistrzostwem - oraz analiza treści, jakie wybrał i jakie odrzucił, są materiałem na osobne ciekawe rozważania.

Z obserwacji tych i, być może, nużącego śledzenia książek, które Krasicki trzymał w ręku, a co istotniejsze - w głowie, kiedy pisał eseje mające złożyć się na jego ostatnie, wydrukowane już pośmiertnie, dzieło, wynika kilka wniosków. Po pierwsze, wyraźne staje się zainteresowanie autora dla literatury i kultury Orientu (a wydaje się, że należałoby je rozciągnąć także na Daleki Wschód, przede wszystkim na Chiny), które nie ograniczało się jedynie do stylizacji w Powiastkach wschodnich, paru artykułów w dziele $O$ rymotwórstwie i rymotwórcach czy haseł w Zbiorze potrzebniejszych wiadomości. Liczba oraz wybór pozycji bibliograficznych dotyczących owej tematyki oraz fakt, że XBW potrafił nie tylko zabłysnąć erudycyjnymi wzmiankami o nich, lecz również przyswoić ich treść do takiego stopnia, by - jak pisał Scott Black - „używać” ich do przedstawienia swoich myśli, przekonań, rad, wskazuje na rzeczywistą znajomość tych lektur. Po drugie, istnieje różnica między posiadaniem biblioteki a korzystaniem $z$ niej. Autor sam zdawał sobie $z$ tego sprawę, proponujac nieczytającym właścicielom takich przybytków, $\mathrm{z}$ charakterystyczną dla siebie pogodną, choć dotkliwą ironią, by zastąpili książki oprawnymi w skórę drewnianymi klockami, co pozwoli im zaoszczędzić pieniądze ${ }^{50}$. Niniejszy artykuł, zainspirowany rozważaniami Teresy Kostkiewiczowej nad znaczeniem lektury, rolą książek i zaletami oraz wadami druku ${ }^{51}$, stanowi, mam nadzieję, niewielki fragment mozaiki literackich upodobań Krasickiego, które pieczołowicie zebrała i przedstawiła we wspomnianym już artykule Magdalena Górska ${ }^{52}$, wyliczając książęce lektury wymienione w przywołanych tu Bibliotekach oraz prezentując dzieła tak mu bliskie, że miał je przy sobie w dniu swojej śmierci. Po trzecie, mimo istnienia wielu studiów nad życiem i twórczością Krasickiego ciągle odnaleźć można białe plamy lub obszary mniej zbadane. Oprócz zaznaczonych wcześniej kwestii warsztatu translatorskiego oraz kryteriów wyboru przekładanych treści warto byłoby prześledzić choćby to, w jaki sposób w Uwagach znalazła się jeszcze jedna klasyczna pozycja z literatury Orientu - perski epos Szahname autorstwa Ferdousiego, z którego pochodzą Maksymy i odpowiedzi Buzura ${ }^{53}$. Badania takie staną się niewątpliwie pomocą dla przyszłych wydawców, badaczy i czytelników pism Księcia Biskupa.

I. Kra s i c ki, Biblioteki. W: Uwagi, s. 116-117.

Chodzi tu m.in. o wspomniany już artykuł „Księgi, wiersze, dzienniki...”

Górs ka, op. cit.

Czy raczej Buzurdžmihra (Bozorgmehra), mądrego wezyra (jakże by inaczej), jednego z bohaterów epopei, który podczas wydawanych przez swojego króla uczt odpowiada na wiele pytań z zakresu moralności i sztuki panowania. Zob. T. Kowals ki, Studia nad Šāh-Nāme / (Études sur Šāh-Nāme). (Avec résumé français). T. 1. Kraków 1952, s. 207, passim. Co ciekawe, dwie maksymy z tych, które znajdujemy u Krasickiego, podaje także, choć w nieco innej wersji, autor kryjący się pod kryptonimem ks. S. J. (Księga złotych myśli z różnych źródeł. Zebrał i według treści uporządkował w 130 rozdziałach i dwóch tomach ks. S. J [a r zy na]. T. 1. Wyd. 2, przer. i popr. Cieszyn [1931], s. 382, 411). Najbardziej zaś zaskakującą rzeczą w całej sprawie jest to, że tajemniczy dla badaczy literatury polskiej Buzur i niezwykłe związki Księcia Biskupa z perską epopeją wcale nie stanowią zagadki dla jej badaczy. Oto jak zaczyna się hasło Šāh-nāma translations into Polish opracowane przez A. Kra s n ow ols ką w Encyclopaedia Iranica (na stronie: https://iranicaonline.org/articles/sah-nama-translations-xiii-into-polish 〈data dostępu: 14 II 2021〉): „Pierwszą krótką wzmiankę o Ferdousim w Polsce uczynił Ignacy Krasicki (1735-1801) w swoim dziele O ry- 
Abstract

KLARA LESZCZYŃSKA-SKOWRON The Institute of Literary Research of the Polish Academy of Sciences, Warsaw

ORCID: 0000-0002-1760-8990

\section{KRASICKI'S ORIENTAL READERS-A CONTRIBUTION TO RESEARCH IN THE WRITER'S ERUDITION}

The paper is devoted to two collections of maxims contained in Ignacy Krasicki's Uwagi (Remarks), namely to Przestrogi, które Nabi Effendi synowi swemu zostawit (Warnings that Nabi Effendi Left to His Son) and to Myśli (Thoughts). The authoress finds the sources from which Krasicki took the maxims (these are the pieces of classical Oriental literature, namely Hayriye by Yusuf Nabi and Historia i madrość (History and Wisdom) by Ahikar of Assyria, she presents their concise history as well as their significance to European literature.

motwórstwie i rymotwórcach [...]. Oprócz tego zamieścił on w swoim zbiorze Powiastek wschodnich dwa fragmenty pochodzące z Šāh-nāmy: O Aleksandrze i filozofie indyjskim oraz Maksymy i odpowiedzi Buzura (właśc.: Bozorgmehr), choć nie podał ich źródła”. Zaznaczyć trzeba, że Maksymy i odpowiedzi są fragmentem Uwag, nie zaś Powiastek wschodnich, choć prawdopodobnie z punktu widzenia iranistów nie jest to szczególnie istotne.

Bardzo dziękuję pani redaktor Agnieszce Magrel za rozszyfrowanie kryptonimu: ks. S. J. 